INTERNATIONAL JOURNAL OF LEGAL INFORMATION

$\begin{array}{llll}\text { February } & 1983 & \text { Vol. } 11 & \text { No. } 1 \\ \text { April } & 1983 & \text { Vol. } 11 & \text { No. } 2\end{array}$

The Official Publication of the

International Association of Law Libraries

\title{
CONTENTS
}

In Memoriam George J. Roman ............... vii

The Liability of the Government in France as a Consequence of Its

Legal Activities by M. Tahar Ahmedouamar .......... 1

International Organization Documentation by Robert W. Schaaf 13 PERIODICAL REVIEWS

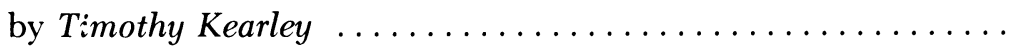

I. New Periodicals

a. South Pacific

Australian Journal of Law and Society ............ 20

The Canterbury Law Review . . . . . . . . . . . . . 20

Journal of Law and Information Science ............ 21

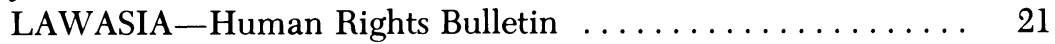

UCLA Pacific Basin Law Journal $\ldots \ldots \ldots \ldots \ldots \ldots \ldots \ldots . \ldots \ldots$

China Law Reporter .................... 22

b. Entertainment Law
Entertainment Law Reporter $\ldots \ldots \ldots \ldots \ldots \ldots \ldots \ldots \ldots \ldots 22$

Entertainment Law Journal . . . . . . . . . . . . . . . 23

Loyola of Los Angeles Entertainment Law Journal . . . . . . . 23

Cardozo Arts and Entertainment Law Journal . . . . . . . . . . 24

c. Recent Other Titles

Civil Justice Quarterly . . . . . . . . . . . . . . . . . 24

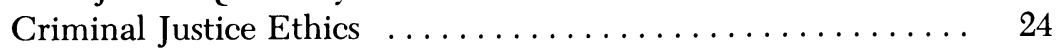

Law and History Review . . . . . . . . . . . . . . 25

Legal Studies. The Journal of the Society of Public

Teachers of Law . . . . . . . . . . . . . . . . . . . . . . . 25

Argomenti: Revista di Studi e Richerche Giuridiche ....... 25

Lex, Revista de la Escuela de Derecho ............ 26

Seqüência: Estudios Juridicose Politicos ............ 26 
II. U.S. Law School International, Transnational and Comparative Law Reviews

\section{THE INTERNATIONAL BOOKSHELF}

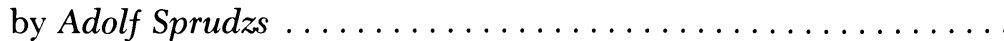

I. Review Essays

BEBR: Development of Judicial Control of the European Communities by Peter Hay

Ellis and Storm: Business Law in Europe by Charles Szladits

Sandalow and Stein: Courts and Free Markets: Perspectives from the United States and Europe by Stephen L. Sass

Schoenblum: Multistate and Multinational Estate Planning

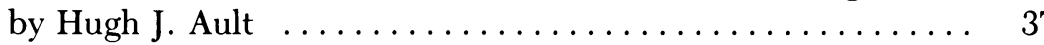

Bilder: Managing the Risks of International Agreement by Richard B. Lillich

Pomerance: Self-Determination in Law and Practice:

The New Practice in the United Nations

by S. Prakash Sinha

Bernhardt: Encyclopedia of Public International Law

by Henn-Jüri Uibopuu

Lewis: Gatley on Libel and Slander

by Richard A. Epstein

Lerrick and Mian: Saudi Business and Labor Law:

Its Interpretation and Application

by Zuhair E. Jwaideh .

Jackson and Powell: Professional Negligence

by Richard A. Epstein

Fridman and McLeod: Restitution

by Daniel C. Turack

Mersky and Others, eds.: Collecting and Managing Rare

Law Books

by George S. Grossman

II. Reviews and Appraisals

Lachs: The Teacher in International Law by John N. Hazard 
Mitchell and Others, eds.: Archbold: Pleading Evidence and Practice in Criminal Cases

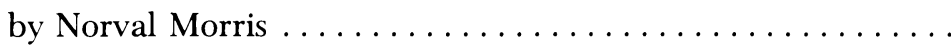

Elkind: Interim Protection-A Functional Approach

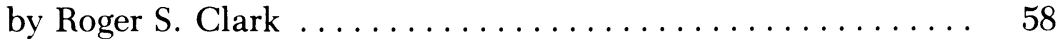

Vom Ende: Criminology and Forensic Sciences: An International Bibliography

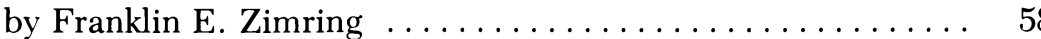

Bowett: The Law of International Institutions by Igor I. Kavass

Schanze and Others: Studies in Transnational Law of Natural Resources by A. Dan Tarlock

Collins: Marxism and Law by John N. Hazard

Lipstein: Principles of the Conflict of Laws:

National and International

by Armins Rusis

Khan: The Law and Organization of International Commodity Agreements by Stephen L. Sass

Peteri and Lamm: Legal Development and Comparative Law

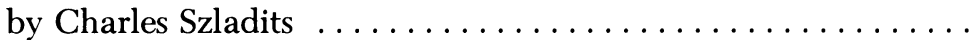

Nee, Chu and Moser: Commercial, Business and Trade Laws: People's Republic of China by Chin Kim

Yusuf: Legal Aspects of Trade Preferences for Developing States: A Study in the Influence of Development Needs on the Evolution of International Law by John M. Lindsey

Kapteyn and Lauwaars: International Organization and Integration by Ivan Sipkov

Chatterjee: Legal Aspects of International Drug Control by Armins Rusis

Jakovljević: New International Status of Civil Defence as an Instrument for Strengthening the Protection of Human Rights by James M. Murray 
Recueil des Conventions/Collection of Conventions

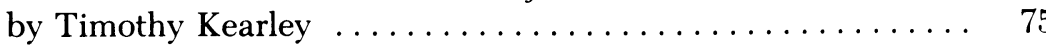

Borrmann and Stegger: The EC's Generalized System of

Preferences

by George Roman

Gold: The Fund Agreement in the Courts: Volume II.

Further Jurisprudence Involving the Articles of Agreement of the IMF

by Ivan Sipkov

Effros: Emerging Financial Centers: Legal and Institutional Framework

by Miklos K. Radvanyi

Aaron: VAT: Experiences of Some European Countries by George Roman .....................

Norr: The Taxation of Corporations and Shareholders by Allaire Urban Karzon ..................... 80

Rosen, ed.: Commercial, Business and Trade Laws: India by S. Prakash Sinha

Chang: China's Boundary Treaties and Frontier Disputes

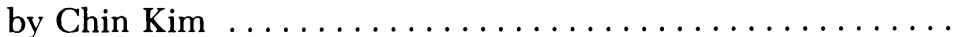

Kim: Business Laws in Korea: Investment, Taxation and Industrial Property by $\mathrm{T}$. Susanne Lee

Weeraratna: The Proposed Foreign Investment Authority Law of Sri Lanka (1976): A Critical Analysis by S. Prakash Sinha

Crawford: Australian Courts of Law by George E. Glos . . . . . . . . . . . . . . . . . . . . .

Papadopoulos: Multilateral Diplomacy Within the Commonwealth: A Decade of Expansion

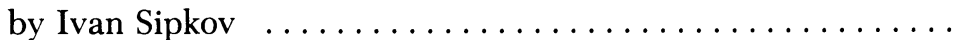

Karatzas and Ready: The Greek Code of Private Maritime Law by David A. Combe

Treves: Lo Sfruttamento dei Fondi Marini Internazionali by George E. Glos

Buckwalter: Law Books in Print by Ivan Sipkov 
Ciampi and Others: THES/BID: A Computer-based Thesaurus of Terminology in Computers and the Law

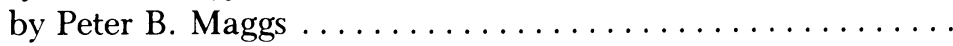

Twining and Uglow: Law Publishing and Legal Information:

Small Jurisdictions of the British Isles

by Lance Dickson .

Kavass and Sprudzs: Current Treaty Index 1982:

A Cumulative Index to U.S. Slip Treaties and Agreements, TIAS 9605-10000

by Stefan A. Riesenfeld

Arroyo: Anuario De Derecho Maritimo

by David A. Combe

Walker: Official Publications of the Soviet Union and Eastern Europe 1945-80: Select Annotated Bibliography by Igor I. Kavass

Ball: Indonesia Legal History 1602-1848

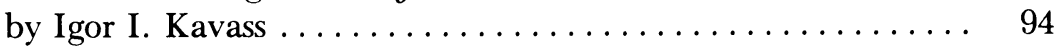

Ball: Bibliography of Material on Indonesian Law in the English Language by Igor I. Kavass . . . . . . . . . . . . . . . . .

III. Book Notes

Kirchner and Kastner: Abkürzungsverzeichnis der Rechtssprache

Marke and Samie: Anti-Trust and Restrictive Business Practices: International, Regional \& National Regulation . . . . . . . . . .

Delvolvé: Arbitration in France: The French Law of National and International Arbitration

Ṡzladits: A Bibliography on Foreign and Comparative Law:

Books and Articles in English. Supplement 1978 . . . . . . . . 97

Comparative Law Yearbook ..................... 97

Gammeltoft-Hansen: Danish Law: A General Survey .......... 98

Government Gazette Index: An Index to the Government Gazette of the Republic of South Africa . . . . . . . . . . . 98

Hamblin and Wright: Introduction to Commercial Law . . . . . . 98

Strömholm: An Introduction to Swedish Law . . . . . . . . . . . 99

Melton: Legal Reforms Affecting Child \& Youth Services . . . . . 99 
Zacklin and Others: The Legal Regime of International Rivers and Lakes ............................ 99

Todd: Limitation Periods in Personal Injury Claims ........ 100

Brown: "O" Level Law .............................. 100

Casson and Dennis: Odger's Principles of Pleading and Practice in Civil Actions in the High Court of Justice .............................. 101

Jacob: The Reform of Civil Procedural

Law and Other Essays in Civil Procedure ............. 101

Books Received ........................... 102, 109

Books Noted .......................... 106, 112

Bibliographies, Dictionaries, Reference Works ........ 106, 112

Comparative Law ....................... 107, 112

European Communities ..................... 107, 112

Human Rights .............................. 107

International Law, International Business Transactions ..... 108, 113

Asia, Australia . . .......................... 108, 113

Eastern Europe, USSR ..................... 108, 113

Western Europe ......................... 109, 114 
Dr. George J. Roman, a senior legal specialist with the European Law Division of the Library of Congress, died on April 17, of a heart attack.

Born on April 5, 1923, in Vraniut, Romania, Dr. Roman graduated from the Bucharest University Law School and passed his State Examination as a government lawyer. He spent his entire legal career, chiefly as a legal advisor, in the Romanian Foreign Affairs Ministry. He was also First Secretary to the United Nations in charge of legal matters. He later served as Foreign and International Law Librarian at Georgetown University Law Center. Dr. Roman was appointed Romanian legal specialist in the European Law Division on February 25, 1980, and was promoted to senior legal specialist in 1981. In the United States, he earned the following degrees: Master's degree in Comparative Law (1967) Georgetown University Law Center; Master's degree in Library Science (1969) Catholic University of America; Doctor's degree in Comparative Law (1972) Georgetown University Law Center.

He spent a substantial portion of his career teaching public and private international law and Romanian law. He was Adjunct Professor of Law at the Georgetown University Law Center where he was teaching a graduate course on private international law of economic contracts. He also served as a Senior Research Fellow and Consultant Librarian of the International Law Institute at this Center. Simultaneously, he served as an Arbitrator at the National Panel of Arbitrators of the American Arbitration Association, as a judge in the Philip C. Jesup International Moot Court Competition organized by the American Society of International Law, and as a member of the Board of Governors of the Washington Foreign Law Society. Dr. Roman was a member of several professional organizations including the American Society of International Law, the International Association of Law Libraries, the American Association of Law Libraries, and the Law Librarians' Society of Washington, D.C. A scholar of note, he was on the Editorial Advisory Committee of the International Legal Materials of the ASIL and authored a great number of outstanding studies and articles on various legal topics. 


\title{
INTERNATIONAL JOURNAL OF LEGAL INFORMATION
}

\author{
EDITORIAL BOARD
}

Editor-in-Chief: $\quad$ ARNO LIIVAK, Professor of Law and Law Librarian, Rutgers University School of Law

Fifth and Penn Streets, Camden, New Jersey 08102 (U.S.A.)

Associate Editors: IGOR I. KAVASS, Professor of Law and Law Librarian,

Vanderbilt University School of Law

Nashville, Tennessee 37203 (U.S.A.)

(News Notes and Comments)

KLAUS MENZINGER, Director, Bibliothek für

Rechtswissenschaft der Universität Freiburg

Werthmannplatz 1, 7800 Freiburg i. Br.

Federal Republic of Germany

(Periodical Review)

IVAN SIPKOV, Chief, European Law Division,

Law Library of Congress, Washington, D.C. 20540 (U.S.A.) (Legislative Perspectives)

ADOLF SPRUDZS, Foreign Law Librarian and Lecturer in Legal Bibliography, The University of Chicago Law School, 1121 East 60th Street, Chicago, Illinois 60637 (U.S.A.)

(The International Bookshelf)

\section{SUBSCRIPTION INFORMATION:}

Rates per subscription-individuals @ $\$ 38$. (U.S.) per year institutions @ \$55. (U.S.) per year

Orders, Claims, and Notices should be addressed to:

IALL Headquarters

c/o Professor Igor I. Kavass

Vanderbilt University School of Law

Nashville, Tennessee 37203 (U.S.A.)

\section{MANUSCRIPT INFORMATION:}

The International Journal of Legal Information invites for publication the submission of manuscripts for articles, bibliographies, notes and correspondence concerning law and law-related information.

All articles, bibliographies or other longer works should be sent to the Editor-inChief. Materials intended for inclusion in any of the other sections of the IJLI should be sent directly to the Associate Editor who has responsibility for the respective section, at the above addresses.

Issued February, April, June, August, October and December.

Copyright @ 1983 by International Association of Law Libraries.

Library of Congress No. 73-81409, ISSN 0731-1265. Printed in the United States. 